J.Biol.Educ. 8 (2) (2019)

\title{
Journal of Biology Education
}

\section{UNNES}

http://journal.unnes.ac.id/sju/index.php/ujbe

\section{Analyzing Pedagogical Knowledge of High School Biology Teachers in Banten Based on Educational Backgrounds}

\author{
Maya Rahayu ${ }^{1}$. S, Suyanto ${ }^{1}$ \\ ${ }^{1}$ Graduate School, Yogyakarta State University, Indonesian \\ ${ }^{2}$ Department of Biology Education, Yogyakarta State University, Indonesian
}

\section{Info Article}

History Article:

Received : June 2019

Accepted : August 2019

Published: August 2019

Keywords:

Pedagogical knowledge,

educational backgrounds,

competences of teacher

\begin{abstract}
Pedagogical Knowledge is a knowledge of teachers which more emphasizing on how teachers formulate the learning plan, method comprehension and approach, curriculum, learning motivation as well as learning evaluation instrument. This research was aimed to discover the skill difference of pedagogical knowledge of biology teachers compared to different educational backgrounds. The method of this research was a quantitative-descriptive through proportional random sampling technique for sample collection. The population of this research was the entire biology teachers in State High School of Lebak Banten. The collected samples were 18 biology teachers with different educational backgrounds. This research was performed in State High Schools spread among the area of Lebak-Banten. The analysis results of the data of pedagogical knowledge question items have indicated that the average teachers with biology education background has higher score (73.33) and $0.033<0.05$ value has acquired based on $t$-test result. It means that there is a significant difference between teachers who have biology education background compared to teachers with non-education background.
\end{abstract}




\section{INTRODUCTION}

Education is the foundation of the progress of a nation. Nations with quality education are established by the availability of professional teachers. Teachers are one of the determinant factors of the education quality in a nation, because teachers are demanded to be able of educating and guiding the children of the nation to conceive decent capabilities, therefore, they able to compete with other nations. This condition is ingrained in the Government Regulation of Indonesia No.74/2008 Article 1 verse 1 regarding teachers as the professional educator with the main tasks to educate, teach, guide, direct, train, assess, and evaluate the learning participants on the formal pathways for early childhood education, basic education, and intermediate education (Goverment regulation, 2008). Because a teacher could determine the quality of an individual, thus, the teacher should conceive the skills that compatible to the provisions regulated by the government. The government of Indonesia has implemented the provisions which should be conceived by teachers in Law No.14/2005 regarding Teacher and Lecturer in which teachers should own several competencies namely pedagogic competence, personality competence, social competence as well as professional competence (National Education, 2005). In principle, competences are the description regarding what can be conducted by an individual in work as well as the showable embodiment of the work (Suyanto, 2013).

In reference to four competencies, the pedagogical competence becomes the basic for a teacher in delivering a material content or knowledge which will be transferred into the learning participant and regarding the method to organize the class to make the expected learning process can be implemented. This matter is included in the Government Regulation No.19/2006 Article 28 Verse 3 regarding National Standards for Education. In the regulation, it is mentioned that the pedagogical competence is the skill in managing the learning process of students which encompasses the comprehension of students, planning and implementation of learning, evaluation of learning outcomes as well as the mastery of students to actualize their self-potentials (Goverment Regulation, 2005).

The effort that can be conducted by a teacher to improve the professional competence is through the competency test program for teacher. Teacher's competency test is a program performed by the government as the mapping for competence and performance of teachers as the basis to apply development for teachers and other education workers to be able of fulfilling minimum service standards (Mulyasa, 2013). Teacher's competency test has standard of value that should be met. This competency test includes professional and pedagogic competencies. Professional competence is associated to the capability of teacher in mastering the material content while pedagogic competence is associated to the capability of teaching in managing and organizing class during the learning process, preparing and planning the implementation of learning, understanding the characteristics of students into knowing the proper evaluation in the learning process.

Through the data of survey results of UKG, it has been known that Banten is still below the standard applied by the government namely 75 (General Directorate of Education, 2012), while the UKG's value for pedagogic filed in Banten area is around 61.75. This condition is certainly caused by some factors. In this research, the researcher attempted to see from the perspective of educational backgrounds. Based on the preliminary survey conducted by disseminating questionnaire regarding educational backgrounds, it has been known that in Banten, there are some teachers of biology subject who came from various 
educational backgrounds which are not compatible with the subject they taught. This condition is suspected to affect the performance of a teacher in delivering the material toward students.

A teacher should own compatible competencies with the provision regulated by the government in Law No.14/2005 regarding Teacher and Lecturer in which a teacher should conceive academic qualifications, competencies, educator certificates, physically and mentally healthy as well as having the capability in embodying the national purpose of education. The competencies that should be conceived by teachers are pedagogic competence, professional competence, personality competence as well as social competence (Naional Education Department, 2005). Pedagogic competence is one of the basic competencies a teacher should own. A teacher should master the pedagogic competence because its correlated to the capability in managing class, organizing the material that will be delivered toward students, the comprehension of curriculum, the characteristics of students, learning motivation, into the evaluation of learning outcomes (Koehler, 2006).

Pedagogical knowledge is a basic knowledge that has to be conceived by teachers to be able of knowing the method to teach and transfer knowledge toward students. Pedagogical knowledge emphasizes the teacher knowledge in understanding students, the way to teach, organize the class, create a planning, organize teaching process as well as the knowledge regarding the media to learning model (Shulman, 1987). The capabilities in organizing class, conducting evaluation, planning as well as developing the potentials of students are not skills that can be have spontaneously, instead, a decent preparation and proficiency is required, because a quality learning is started from the preparation which based on good quality as well. A teacher with good pedagogic knowledge could understand the way to make the students establish their own knowledge as well as develop their own thinking habits. This knowledge is included in cognitive and social comprehensions as well as learning theory (Mishra, 2006).

Background in education major becomes one of the contributing factors in the success of students to achieve education purpose which compatible with government regulation. A teacher with compatible qualification between the field and subject he/she taught will have more understanding toward pedagogical knowledge. Background in education can be made as the standard for a teacher to be determined as professional or not, such as proposed by Sudarwan Danim (2002:30) in which the professionalism of a teacher can be seen from two perspectives, namely background in education and proficiencies of teachers toward teaching materials, organizing learning as well as managing students (Danim, 2002). According to Government Regulation No.19/2005 Article 28, it is mentioned that education has to conceive academic qualifications and competencies as the learning agent, physically and mentally healthy as well as having the capabilities to embody the national purpose of education (Goverment Regulation, 2005).

\section{RESEARCH METHOD}

This research was a survey study with qualitative-descriptive method. This research was performed in March 2019 on odd semester. The population in this research was biology teachers in State High School spread among Lebak-Banten. The samples were consist of 18 biology teachers who taken from several state schools in Banten with different backgrounds. The sample collection was performed through proportional random sampling because it 
considered the need over variables which will be studied. The distribution of biology teacher sample with different backgrounds can be seen through the table as follows.

Table 1. Sample distribution of biology teachers in Lebak-Banten

\begin{tabular}{|c|c|c|c|}
\hline No. & Name of Schools & $\begin{array}{c}\text { Number of } \\
\text { Biology Teacher }\end{array}$ & Educational Backgrounds \\
\hline 1. & State High School A & 1 & Bachelor Degree of Biology Education \\
\hline 2. & State High School B & 2 & $\begin{array}{l}\text { Bachelor Degree of Biology Education } \\
\text { Bachelor Degree of Agriculture } \\
\text { Bachelor Degree of Biology Education }\end{array}$ \\
\hline 3. & State High School C & 2 & $\begin{array}{l}\text { Master Degree of Educational Research and } \\
\text { Evaluation }\end{array}$ \\
\hline 4. & State High School D & 1 & Bachelor Degree of Biology Education \\
\hline 5. & State High School E & 2 & $\begin{array}{l}\text { Master Degree of Biology Education } \\
\text { Master Degree of Agriculture }\end{array}$ \\
\hline 6. & State High School F & 1 & Bachelor Degree of Biology \\
\hline 7. & State High School G & 2 & $\begin{array}{l}\text { Bachelor Degree of Biology Education } \\
\text { Bachelor Degree of Biology Education }\end{array}$ \\
\hline 8. & State High School H & 2 & $\begin{array}{l}\text { Bachelor Degree of Biology Education } \\
\text { Bachelor Degree of Biology Education }\end{array}$ \\
\hline 9. & State High School I & 2 & $\begin{array}{l}\text { Bachelor Degree of Biology Education } \\
\text { Bachelor Degree of Biology }\end{array}$ \\
\hline 10. & State High School J & 1 & Bachelor Degree of Biology \\
\hline 11. & State High School K & 1 & Bachelor Degree of Biology \\
\hline 12. & State High School L & 1 & Bachelor Degree of Agricultural Technology \\
\hline Total & & 18 & \\
\hline
\end{tabular}

The instrument used to acquired data in this research was test question items which consist of 15 questions of pedagogical knowledge, observation sheet of learning implementation and lesson plan documents. The instrument have been gone through face validity process by expert judgement and have been tested on several teachers in different area but still compatible with the variables that studied by the researcher. The question instrument of pedagogical knowledge provided toward biology teachers of State High School consists of several aspects. Those aspects were synthesized through theories proposed by the experts as well as adjusted to the curriculum. These are the aspects of knowledge and indicators used to create pedagogical knowledge questions.

Table 2. Aspects of knowledge and indicators of pedagogical knowledge question instrument Aspects of knowledge Indicators

Analyzing 2013 curriculum in biology Analyzing the basic competence on reproduction system field Analyzing the correlation between basic competency and competency achievement indicators on human reproduction system

Analyzing the study and learning Understanding the scientific activities on reproduction system theory on 2013 curriculum material

Identifying the developments of Understanding the cognitive development in reference to Piaget cognitive, attitude, and skill of on reproduction system material

students on reproduction system

Understanding the cognitive development according to Bloom and Krathwohl and its application on reproduction system material

Understanding the development of attitude based on Masia on biology learning

Understanding the development of skills in reference to Simpson and its implementation on reproduction system

Understanding the development in accordance with Dyers on biology learning 
Analyzing the types of self-motivation Understanding basic physiological needs which affect the on students based toward Abraham students

Maslow to study the biology field Analyzing self-actualization (meta-needs) which affects students

Identifying the evaluation technique Identifying the government regulation regarding the evaluation based on 2013 curriculum technique of learning

These data are the test results of pedagogical skill, and and an observation sheet on the implementation of biology teachers in Lebak-Banten. After the data were obtained, the differences between teachers with linear background of education and teachers with noneducation/non-linear status were searched to discover the pedagogic skill of those teachers. After the result scores of pedagogical knowledge test have been acquired, then, the differential test was performed through independent t-test. The prerequisite test such as normality and homogeneity tests have been conducted in prior before performing t-test. This t-test was performed to discover whether there is a difference between teachers with biology education background and teachers with non-education background.

\section{RESULTS AND DISCUSSION}

The results obtained through pedagogical knowledge questions provided by the researcher on biology teachers in State High School in Lebak-Banten can be seen in the table as follows:

Table 1. Scores of Pedagogical Knowledge test of biology teachers in Lebak-Banten.

\begin{tabular}{crrll}
\hline \multirow{2}{*}{ Teachers } & \multicolumn{3}{c}{ PK } & Background in Education \\
\cline { 2 - 4 } & Score & (\%) & Information & \\
\hline 1 & 9 & 60 Decent & Non Education \\
3 & 13 & 86.67 Very Good & Non Education \\
4 & 9 & 60 Decent & Non Education \\
5 & 3 & 20 Very Poor & Non Education \\
6 & 12 & 80 Good & Education \\
7 & 9 & 60 Decent & Education \\
8 & 13 & 86.67 Very Good & Education \\
9 & 11 & 73.33 Good & Education \\
10 & 11 & 73.33 Good & Education \\
11 & 9 & 60 Decent & Education \\
12 & 11 & 73.33 Good & Non Education \\
13 & 12 & 80 Good & Education \\
14 & 11 & 73.33 Good & Education \\
15 & 8 & 53.33 Decent & Non Education \\
16 & 8 & 53.33 Decent & Non Education \\
17 & 10 & 66.67 Good & Education \\
18 & 12 & 80 Good & Education \\
\hline
\end{tabular}

The ability of pedagogical knowledge in this research addition to being measurd using a test, the researcher also observed the learning process by biology teachers on the material 
of reproductive system in the classroom by used an observation sheet of implementation. The result of observation aspect implementation of learning and comformity RPP for Biology education is 73,1 but non biology education is 65,4 . Prerequisite tests (normality and homogeneity) were performed before the researcher conducted t-test. These tests have been performed to discover whether the acquired data were distributed normally and homogenous or not. The results of normality and homogeneity tests can be seen through the table as follows.

Table 2. Normality Test

\begin{tabular}{|c|c|c|c|c|c|c|c|}
\hline & \multirow{2}{*}{ Teacher } & \multicolumn{3}{|c|}{ Kolmogorov-Smirnov ${ }^{a}$} & \multicolumn{3}{|c|}{ Shapiro-Wilk } \\
\hline & & Statistic & Df & Sig. & Statistic & df & Sig \\
\hline \multirow[t]{2}{*}{$\mathrm{PK}$} & Education & .200 & 10 & .200 & .918 & 10 & .344 \\
\hline & Non Education & .200 & 8 & .048 & .903 & 8 & .310 \\
\hline
\end{tabular}

Lilliefors Significance Correction

*. This is a lower bound of the true significance.

Table 3. Test of Homogeneity of Variance

\begin{tabular}{llrrrr}
\hline & Levene Statistic & df1 & df2 & Sig. \\
\hline \multirow{2}{*}{ PK } & 1.523 & 1 & 16 & .235 \\
& Based on Mean & 1.518 & 1 & 16 & .236 \\
Based on Median & & & & \\
Based on Median and with & 1.518 & 1 & 9.787 & .247 \\
adjusted df & 1.521 & 1 & 16 & .235 \\
Based on trimmed mean & & & & \\
\hline
\end{tabular}

T-test was performed to see whether there is a significant difference between the pedagogical knowledge of teachers with education background and the teachers with noneducation background. The t-test results can be seen through the table as follows.

$\underline{\text { Tabel 4. Independent Sample Test }}$

$\begin{gathered}\text { Levene's Test } \\ \text { for Equality of } \\ \text { Variances }\end{gathered}$
t-test for Equality of Means

\begin{tabular}{|c|c|c|c|c|c|c|c|c|c|c|}
\hline & & \multirow[b]{2}{*}{$\mathbf{F}$} & \multirow[b]{2}{*}{ Sig. } & \multirow[b]{2}{*}{$T$} & \multirow[b]{2}{*}{ Df } & \multirow{2}{*}{$\begin{array}{l}\text { Sig. (2- } \\
\text { tailed) }\end{array}$} & \multirow{2}{*}{$\begin{array}{c}\text { Mean } \\
\text { Difference }\end{array}$} & \multirow{2}{*}{$\begin{array}{l}\text { Std. Error } \\
\text { Difference }\end{array}$} & \multicolumn{2}{|c|}{$\begin{array}{l}95 \% \text { Confidence Interval } \\
\text { of the Difference }\end{array}$} \\
\hline & & & & & & & & & Lower & Upper \\
\hline \multirow[t]{2}{*}{ PK } & $\begin{array}{c}\text { Equal variances } \\
\text { assumed }\end{array}$ & 1.523 & .235 & 2.330 & 16 & .033 & 2.375 & 1.019 & .214 & 4.536 \\
\hline & $\begin{array}{l}\text { Equal variances } \\
\text { not assumed }\end{array}$ & & & 2.158 & 9.399 & .058 & 2.375 & 1.101 & -.099 & 4.849 \\
\hline
\end{tabular}

According to analysis results of pedagogical knowledge scores obtained from 10 teachers with education background and 8 teachers with non-education background, it has been known that the average scores of non-education teachers are amounted to 57.49 , while teachers with education background have average value of 73.33. This condition has indicated that teachers with linear education background have higher proficiency of pedagogical knowledge compared to teachers from non-education background. This result has described that teachers with education background can have more comprehension about curriculum, approach, and learning model, learning motivation of student, and the selection of evaluation in the learning process compared to teachers with non-education background. 
This result is strengthened also through questionnaire of educational backgrounds provided toward the related teachers. In the questionnaire, averagely, teachers with education background have followed more workshops to improve their knowledge regarding education and that based on observations of the implementation of the learning of teachers with biological education background has a higher average. This result is supported by the statement of Andini\&Supardi (2018), that the pedagogical ability of teachers has a strong relationship with educational background so that it affects the efectiveness of learning. Yusof \& Zakaria (2015), base on research assumsed the teaching and learning process requires a teacher who understands the components of content knowledge, and pedagogical knowledge of the content can be applied in class.

The results of prerequisite tests have indicated that the collected data were distributed normally and homogenous. The normality test was performed to discover whether each variable that being studied is distributed normally or not. According to the normality test, the score of pedagogical knowledge for teachers with education background was amounted to $0.344(0.344>0.05)$, and the score of pedagogical knowledge for teachers with noneducation background was amounted to $0.310(0.310>0.05)$ which means that the data were distributed normally. While $0.235(0.235>0.05)$ score has acquired for the homogeneity test. The homogeneity test was performed whether the acquired data have the same variance (homogenous) or not. According to the results of the homogeneity test, the data have homogenous variance. The next action which being conducted was t-test to discover the difference between pedagogical knowledge skill of teachers with different educational backgrounds. It has been known that $0.033(0.033<0.05)$ value of $t$-test has been obtained from t-test. This result means that there is a significant difference between pedagogical knowledge skill of biology teachers with education as their basic and teachers with different educational backgrounds. This condition is seen from the scores acquired when teachers filled the pedagogic questions as well as seen from the background questionnaire which being provided. Based on the questionnaire, teachers with education as their qualification have followed more workshops compared to teachers with non-education background. Therefore, it can be said that the teachers have comprehended more pedagogic knowledge because they have participated in various trainings held by the government. Pedagogic knowledge has to be mastered by teachers because it is the basic to transfer knowledge toward students. This result is supported by the statement of Mulyasa (2008) in which the pedagogic competence is crucial because it becomes the determinant of the success of learning process that touches directly the managerial skills of learning which include students, planning, implementation, designing, learning outcome, evaluation, and the development of under-achievement students (Mulyasa, 2008).

\section{CONCLUSION}

According to the results that have been conducted, it can be concluded that teachers with the background of biology education have an average score higher than non biological education teachers. This condition means that there is a difference of pedagogical knowledge skills between non-education teachers and teachers with education background. Therefore, teachers with biology education have more comprehension about biology curriculum, the planning that should be done in prior to learning process, compatible model and method as well as learning evaluation. 


\section{REFERENCES}

Andini, D. M., \& Supardi, E. (2018). Kompetensi pedagogik guru terhadap efektivitas pembelajaran dengan variabel control latar belakang pendidikan guru. Jurnal Pendidikan Manajemen Perkantoran.Vol 3 No.1, Hal 149-155.

Arikunto, Suharsimi. 2012. Prosedur Penelitian. Suatu Pendekatan Praktik (Edisi Revisi VI). Jakarta: PT.Rineka Cipta.

Danim, Sudarwan. 2002. Menjadi Penelitian Kualitatif. Bandung: Pustaka Setia.

Government Regulation No.19/2005 Article28 verse 3 regarding National Standard of Education.

Government Regulation No.74/2008 regarding Teacher. Jakarta: PPRI.

Koehler, M. J., Shin, T. S., \& Mishra, P. (n.d.). How Do We Measure TPACK? Let Me Count the Ways. Educational Technology, Teacher Knowledge, and Classroom Impact, 16-31. https://doi.org/10.4018/978-1-60960-750-0.ch002

Mishra, P. and M.J Koehler. 2006. Technological Pedagogical Content Knowledge: A Framework for Teacher Knowledge. Teachers Collage Record. 6 (108): 1017-1054.

Mulyasa. 2008. Menjadi Guru Profesional. Bandung: PT Remaja Rosdakarya

Mulyasa. 2013. Uji Kompetensi dan Penilaian Kinerja Guru. PT.Rosda Karya.Bandung

Shulman, L., S. 1987. Knowledge and teaching: Foundations of the new reform. Harvard Educational Review, 57, 1-22.

Suyanto., and Djihad, A. 2013. Bagaimana Menjadi Calon Guru dan Guru profesional. Yogyakarta: Multi Pressindo.

Yusof, Y. M., \& Zakaria, E. (2015). The integration of teacher's pedagogical content knowledge components in teaching linear equation. International Education Studies, 8(11), 26. https://doi.org/10.5539/ies.v8n11p26 